\title{
Assessment and Mapping of the Vulnerability of Soils in Imo State, Nigeria to Erosion Hazard Using Geographic Information System
}

\author{
Emeka Udokporo', Martin Atu Ngozika Anikwe, ", Kevin Ejike Chukwu ${ }^{1}$ \\ ${ }^{1}$ Department of Geography and Meteorology, Enugu State University of Science and Technology, Enugu, Nigeria \\ ${ }^{2}$ Department of Agronomy and Ecological Management, Enugu State University of Science and Technology, Enugu, Nigeria
}

Email address:

anikwema@yahoo.co.uk (M. A. N. Anikwe)

\section{To cite this article:}

Emeka Udokporo, Martin Atu Ngozika Anikwe, Kevin Ejike Chukwu. Assessment and Mapping of the Vulnerability of Soils in Imo State, Nigeria to Erosion Hazard Using Geographic Information System. International Journal of Environmental Monitoring and Analysis.

Vol. 3, No. 5, 2015, pp. 245-259. doi: 10.11648/j.ijema.20150305.12

\begin{abstract}
Soil erosion by water is a critical problem in Imo State terrain due to anthropogenic pressure on its landscape. Assessment and mapping of erosion prone area is essential for soil conservation and watershed management. The objectives of the study are to use satellite imageries to assess and map the land cover, vegetation, land use, topography and hydrology; and to use field sampling to map soil properties and soil erodibility of Imo State with a view to assessing soil erosion hazard in Imo State. The DEM was generated to prepare slope map, elevation map and hill shading map. Results from the study show that $45.4 \%$ of the land cover of Imo State representing $2256.7 \mathrm{Km}^{2}$ is covered by light vegetation whereas $24.7 \%$ of the land area representing $1229 \mathrm{Km}^{2}$ is covered by thick vegetation. The result also showed that a large percentage of the entire land area $(21 \%)$ representing $1046.3 \mathrm{Km}^{2}$ is cultivated whereas $6.4 \%$ representing $319 \mathrm{Km}^{2}$ is built up with houses and infrastructure like roads, bridges etc. The area covered by thick vegetation (24.7\%) is categorized under slightly vulnerable to stable. A larger percentage ( $45.4 \%$ ) is covered by light vegetation, and therefore, classified as moderately vulnerable to erosion whereas $27.4 \%$ comprising cultivated and built up areas are classified as highly to extremely vulnerable to erosion. Results also show that most parts of the state $\left(4133 \mathrm{Km}^{2}\right)$ representing $84 \%$ of the entire landscape fall into slightly to less vulnerable to erosion with a slope class between $1-4 \%$ slope. The results on hill shading concur with that of slope above. As expected, the dispersion ratios were affected by the type of underlying parent material. Results from the characterization of soil properties of study area show since most soils in the study area have high dispersion rates, depicting high vulnerability to soil erosion and $84 \%$ of the entire landscape fall into slightly to less vulnerable to erosion with a slope class between $1-4 \%$ slope, it then follows that high rates of erosion recorded for the area may be due to land use and management as light vegetation, cultivation and built areas cover $73 \%$ of the land area and classified as moderately to extremely vulnerable to erosion. The result at landscape and plot scale varies. Therefore, model results need to be carefully used for local level soil conservation planning.
\end{abstract}

Keywords: Assessment, Mapping, Vulnerability, Gully Erosion, Nigeria

\section{Introduction}

Globally, environmental issues have become major concern to governments and citizens of various nations, including Nigeria. The environment, which is at the heart of economic, social, cultural and human activities, has been disrupted by man's neglect and abuse of the environment. Pollution, deforestation, erosion, landslides, global warming etc. are the aftermaths of this abuse in the ecosystem. The issue of protection, mapping and monitoring becomes paramount in the face of the increasing population of residents in the southeast geopolitical zone of the country. They are severely impoverished, particularly, the rural dwellers due to environmental degradation and increasing population impact on the environmental resources.

Southeastern Nigeria is a typical gully erosion region in Nigeria. The presence of gully sites is one of the hazard features that characterize this zone as well as other States that adjoin them (Ofomata, 1985). Agulu-Nanka in Anambra State is an area badly affected by water erosion. Up to 250 tonnes per hectare of soil have been lost in severe storms. Similarly, Asiabaka and Boers (1988) had estimated that 
over 1,970 gully sites occur in Imo and Abia States. A conservative assessment shows the distribution of known gully sites, in different stages of development are as follows; Abia (300), Anambra (700), Ebonyi (250), Enugu (600), Imo (450) (Igbokwe et al. 2003) (Egboka, 2004).

In Imo State, the impact of gully erosion has been unimaginable, displacing communities and causing destruction of farm lands. However, human activities like land-clearing, and deforestation, overgrazing, as well as the creations of firewood tracks accelerate the natural rates of these processes (Ogbonna, 2012). The immediate site effect is the loss of soil while the off-site effects include the yield of sediment on the river network, which results in declining water quality and damage to the hydraulic structures. It is, therefore, necessary to assess and to manage areas that are vulnerable to gully erosion in order to mitigate any damage associated with it. Gullies are triggered by man's activities, rainfall erosivity and soil erodibility (Ogbonna, 2012).

Gully Erosion is, however, a prominent feature in the landscape of Imo State. The topography of the area as well as the nature of the soil contributes to speedy formation and spreading of gullies in the area.

The resultant need to predict gully occurrences has led to the development of numerous stochastic and process-based models, with increasing emphasis on the use of the Geographic Information Systems (GIS), Satellite Remote Sensing (SRS) and Geostatistical models.

Inspite of technological advancement, erosion menace still remains a major problem in Nigeria (especially in South Eastern Nigeria). The yearly heavy rainfall has very adverse impacts altering existing landscape and forms. Such landforms create deep gullies that cut into the soil. The gullies spread and grow until the soil is removed from the sloping ground. Gullies when formed expand rapidly coupled with exceptional storm or torrential rain down the stream by head ward erosion gulping up arable lands, economic trees, homes, lives, sacking of families, valuable properties that are worth millions of naira. As a matter of fact, there is a direct correlation between development and the effect of gully erosion.

In order to protect the environment and the natural resources for the future generations, it is important to assess and map areas of Imo State that are vulnerable to gully erosion. There is dearth of information on the number, types and stages of gully erosion in different parts of Imo State. More importantly, very little information exist on the vulnerability of soils in Imo State to gully erosion. Much model-derived information on rates of erosion and on erosion risk of cultivated land may be of dubious value, and thus, there is need for other ways to assess vulnerability of soils in Imo State to gully erosion. In developing a sustainable remediation procedure, an assessment of risk of erosion through a spatial mapping of the areas vulnerable to gully formation is necessary.

Hence, in order to plan for a better environmental decision-making policy, the economic evaluation of these environmental problems is important, hence the decision to carry out this research.

The main objectives of the study is to assess and map the vulnerability of parts of Imo State, Nigeria to gully erosion hazard using geographic information system, remote sensing techniques as well as field sampling techniques.

The specific objectives are:

1. To use satellite imageries to map the land use and management, vegetation and land cover, topography and hydrology of Imo State, Nigeria with a view to assessing soil erosion hazard in Imo State.

2. To use field sampling to map soil properties and soil erodibility with a view to assessing soil erosion hazard in Imo State.

\section{Materials and Methods}

\subsection{Study Site}

Imo State occupies the area between the lower River Niger and the upper and middle Imo River. Imo State is bounded on the east by Abia State, on the west by the River Niger and Delta State; and on the north by Anambra State, while Rivers State lies to the south. Imo State covers an area of about $5,100 \mathrm{sq} \mathrm{km}$. Imo state lies within latitudes $4^{\circ} 45^{\prime} \mathrm{N}$ and $7^{\circ} 15^{\prime}$ $\mathrm{N}$ and longitudes $6^{\circ} 50^{\prime} \mathrm{E}$ and $7^{\circ} 25^{\prime} \mathrm{E}$ (Okoro et al. 2014)

Imo State is underlain by the Benin Formation of coastal plain sands. This formation, which is of late Tertiary age, is rather deep, porous, infertile and highly leached. In some areas, impermeable layers of clay occur near the surface, while in other areas, the soil consists of lateritic material under a superficial layer of fine grained sand. Ogbonna (2012) noted that seven (7) geologic formations cover the old Imo State, these are:

(1) Niger Delta Formation - consist of sands, gravels, clays mainly arenaceous with very low dip structure to the SSW;

(2) Coastal Plain Sands Formation - consists principally of sands, gravels, clays, shales (lignites). Topographycally, it consists of gently sloping plain;

(3) Bende Ameke Group Formation - lithologies are clastic sedimentary rocks consisting mainly of lignites conglomerates with interbedded sandstones, and shales.

(4) Imo Shales Formation - consists of clay-shales with intra-formational sand bodies. It is typified with lowland ridges.

(5) This formation is generally called The Plateau and Escarpment made up of three groups: Upper Coal Measure, False Bedded Sandstone, and Lower Coal Measures lithologies are sands, gravels, siltstones, sandstones and grits. The topography consists of minor cuesta, mesas and escarpment.

(6) This formation consists of - Asata-Nkporo Shale, Awgu-Ndeaboh Shale Group, Ezeaku Shale Group, and Asu River Group. Lithologies are shale with lenticular sand bodies, thin limestones, and minor sandstone lenses with igneous bodies.

(7) Asu River Group Formation - consist of crystalline rocks, with topography of mountain terrain with plan ted 
margins.

The type of geology and soil of an area plays an important factor in the development of gully erosion. Rivers are few with vast inter fluves which are characterised by dry valleys that carry surface drainage in periods of high rainfall. The phenomenal monotony of the terrain may be accounted for by the absence of any tectonic disturbances and by the homogeneity of the rock structure (Udo, 1970). The main streams draining the state are Imo, Otamiri, Njaba and Ulasi rivers, all of which have very few tributaries. With the exception of Imo River, which runs through the area underlain by the Imo Shales, other rivers rise within the coastal plain sands. Generally, river valleys constitute the major physical features, which are often marshy.

The undulating nature of the interfluves gives rise to numerous depressions especially in the northeast Rainfall distribution is bimodal, with peaks in July and September and a two week break in August. The rainy season begins in March and lasts till October or early November. From March to May, there are violent storms which destroy crops and houses. Rainfall is often at its maximum at night and during the early morning hours.

However, variations occur in rainfall amount from year to year. Annual rainfall varies from 1,990 to $2,200 \mathrm{~mm}$. Temperatures are similar all over the state. The hottest months are January to March, with the mean annual temperature above $20^{\circ} \mathrm{C}$. The influence of the harmattan lasts for about nine weeks (i.e. from late December to late February).

Imo State has an average annual relative humidity of 75 percent which is highest during the rainy season, when it rises to about 90 percent. The high temperature and humidity experienced in the state favour luxuriant plant growth, which ideally should produce the climax vegetation of the tropical rain forest.

Economic trees like the iroko (Chlorophora excelsa), mahogany (Swietenia macrophylla), obeche (Triplochiton scleroxylon), Gmelina (Gmelina aborea), bamboo (Phyllostachys edulis), rubber (Ficus elastica) and oil palm (Elaeis guineensis) pre dominate. But due to high population density, most of the state has been so farmed and degraded that the original vegetation has disappeared. Thus farmers are forced into marginal lands, a situation aggravated by the rising demand for fuelwood. Deforestation has triggered off acute soil erosion in the study area.

\subsection{Data Acquisition}

The data collected for the study were classified into primary and secondary data. Secondary data source includes information on rainfall distribution from January to December, 1982-2013 collected from records of Nigeria Meteorological Agency (NIMET). Existing road network, settlement distribution, administrative map, drainage patterns and vegetation/land use was obtained from ASTAL Uyo whereas geology, rainfall, relief, and soil maps printed and published by Ministry of Lands, Survey and Urban Planning, Owerri, Imo State from 1980-date were collected. The primary data for this research work is a satellite image and boundary map of Imo State. The States Ministry of Lands and Urban Development provided the administrative map of Imo State as compiled by the States survey division. The analogue map was scanned and the boundary extracted using ArcGIS software. Landsat 7 ETM+ and Landsat 4-5 satellite imagery were adopted for this research after due consideration because of the suitability of the resolution of the satellite and their spectral characteristics. Landsat imageries were stored using aclassification method of paths and rows. United States Geological Survey (USGS) website serves as a repository for archived Landsat satellite imagery. This research was carried out using Global Mapper v12, a raster based Geographical Information System, ArcGis 9.3, a vector based Geographical Information System.

A total of 40 systematic sampling polygons were established throughout the State boundary. The downloaded satellite imagery band 1, 2, 3,4,5,7 were imported in Arc Map 9.3 satellite imagery and the composite tool was used to combine all the bands (panchromatic in appearance) to form a multi-spectral imagery. The Red, Green, Blue (RGB) of the image was set at R-Band 7, Blue-Band 5 and Green-Band 3 to form a true colour imagery.

The 40 systematic sampling polygons created were used as input to create unique signature in Arc Map by using GIS facilities. Then, all sampling plots located with either of the 3-uniques classification of Thick Vegetation, Light Vegetation and Non Vegetation (includes roads, buildings, and hills).

Image enhancement and classification

In this research, principal components and direct adjustment of brightness were used in order to obtain strong contrast between pixels and to create new images. These new images were used, as extra bands, in order to improve image classification techniques. In order to classify land cover within the study area, Image classification was made using supervised techniques, which require that the analyst have distinctive spectral signatures for all types of land cover classes. After accuracy assessment of all used methods maximum likelihood method was used for the classification.

\subsection{Fieldwork}

A reconnaissance survey was carried out in the in the study area to identify sampling points. Sampling points were chosen in each selected site using free survey technique (observation points that are representative of the site are chosen by the surveyors based on personal judgment and experience) (Mulla and McBratney, 2000).The 5 soil groups representing soils formed over alluvium, coastal plain sands, Imo shale clay, and upper coal measures were selected. Three auger and three core samples were collected from $0-20 \mathrm{~cm}$ depth in each of the site.

The auger samples were composited and its sub-samples used for analysis whereas the core samples were analyzed separately and mean results computed and used for statistical analysis. Differences in management practices and edaphoclimatic properties of the soils influenced the choice of the different sites. Sampled locations are shown in Fig. 1 . 


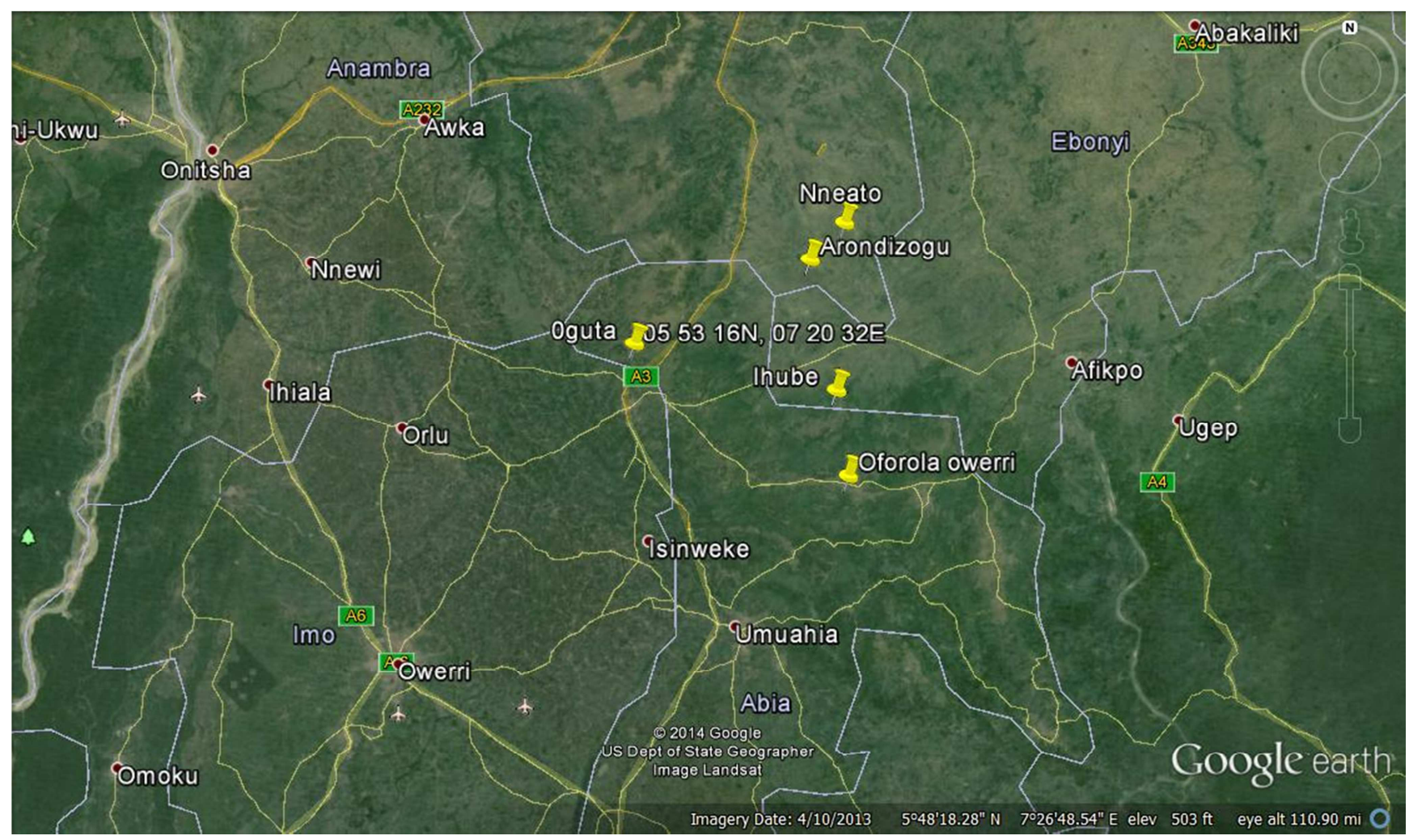

Fig. 1. Sampling Locations in the Study area (from Google Earth, 2014).

\subsection{Laboratory Analyses}

Soil samples were air-dried and sieved using 2-mm mesh sieve before laboratory determinations. Particle size distribution was determined in both distilled water and calgon by hydrometer method (Gee and Bauder, 1986). Thereafter dispersion ratio, used as indirect measures of erodibility was computed as follows:

Erosion index $(\mathrm{EI})=\frac{D R}{\% C L A Y 1 / 2 W H C}$

Where DR $=$ dispersion ratio

WHC $=$ Water holding capacity

Dispersion ratio $(\mathrm{DR})=\frac{\% \text { silt }+\% \text { clay }\left(\mathrm{H}_{2} \mathrm{O}\right)}{\% \text { silt }+\% \text { clay }(\text { calgon })}$

Particle size distribution (textures) was obtained by the hydrometer method (Gee and Bauder, 1986). Soil water holding capacity was determined on undisturbed samples as the difference of water contents at $-0.03 \mathrm{MPa}$ determined by pressure plate and water content at $-1.5 \mathrm{MPa}$ determined by pressure membrane (Dane and Hopmans, 2002).

Erodibility Classes

For the purpose of this study, five erodibility classes were used to depict the vulnerability of the soil to erosion as follows:

1. Extremely vulnerable

2. Highly vulnerable

3. Moderately vulnerable

4. Slightly vulnerable

5. Less vulnerable

\section{Results and Discussion}

\subsection{Land Use and Management}

The results of the study show that $33.6 \%$ of the total land cover of Imo State is cultivated, and therefore, highly vulnerable to soil erosion depending on the management of the soils (Fig. 5). However, only a small portion (9.1\%) actually contains human settlements and buildings including road networks (Fig. 3 and 4).The area coveringsettlements and road networks are classified as highly vulnerablebecausehumanactivities increase soil erodibility rates.Human intervention increases with population growth and pressure. For example, based on his study in the Gauche catchment area (234 ha) in West Hararghe zoneKenya, Thomas (1991) reported that of all the visible erosion incidents, $81 \%$ were caused by human induced factors while the rest were by natural factors. The most common human-induced factors that cause accelerated erosion include deforestation, inappropriate agricultural practices such as over cultivation and overgrazing. Croplands and pastures are susceptible to erosion but croplands are more vulnerable because the soil is repeatedly tilled and left without a protective cover of vegetation. The socio-economic situation in rural areas often leads people to use their environment inappropriately which induce land degradation. In any area the type of land use affects the level of soil protective cover and consequently the rate of erosion and erodibility. Deforestation 
and the removal from the fields of dung and crop residues for fuel and feed causes a steady reduction in the organic matter content of highland soils, rendering them less productive and more easily erodible.

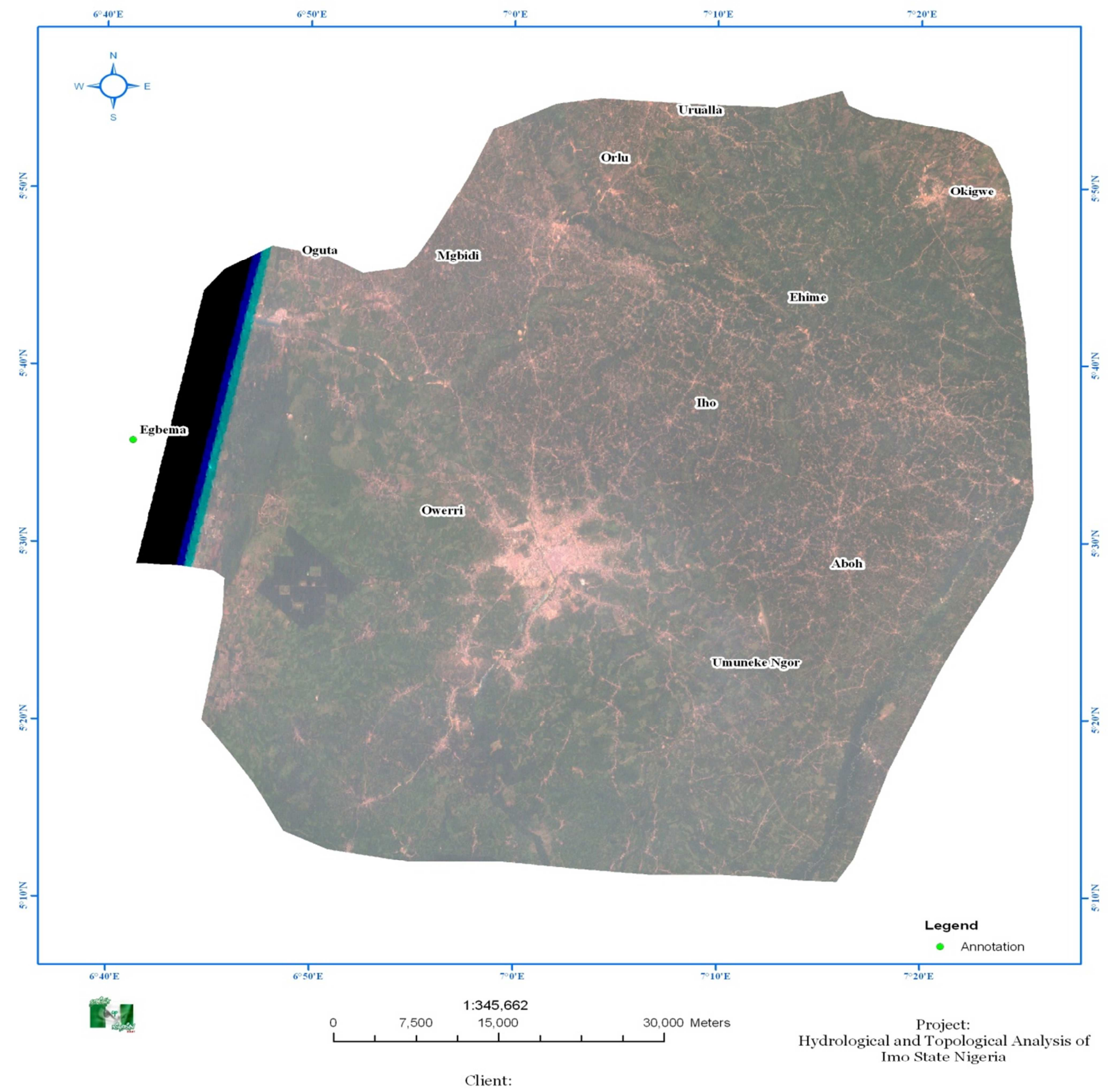

需

Gear-Up Coced by:

Suite D5, Bethel Plaza

Okpara Avenue Enugu Enugu State

08072187110
MAP INFORMATION

Map Projection : UTM ZONE 32N

Date: August 2014

Datum: WGS 84
Title:

Road Network Map of Imo State Nigeria

Fig. 2. Satellite imagery of Imo State. 


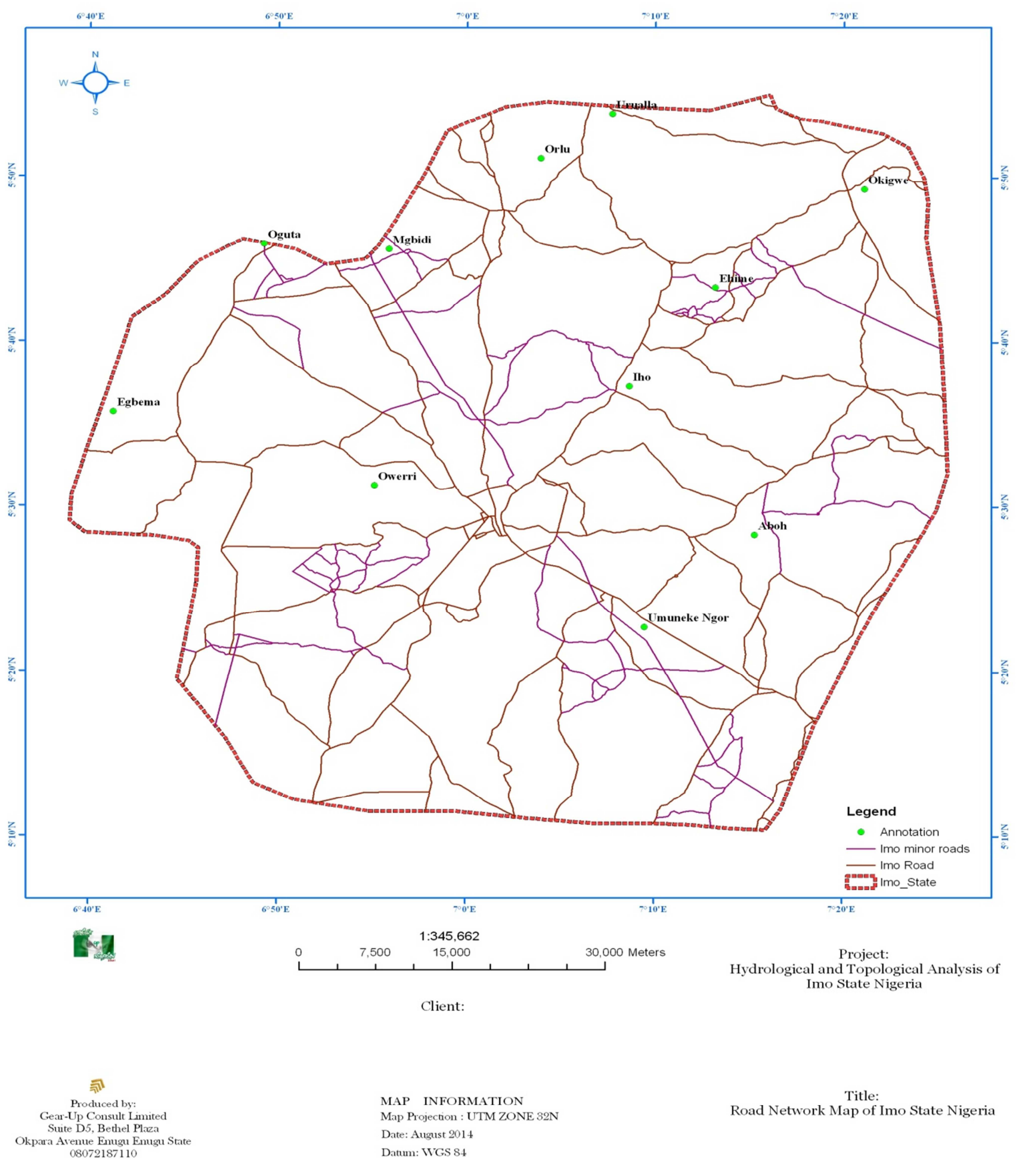

Fig. 3. Road network map of Imo State. 


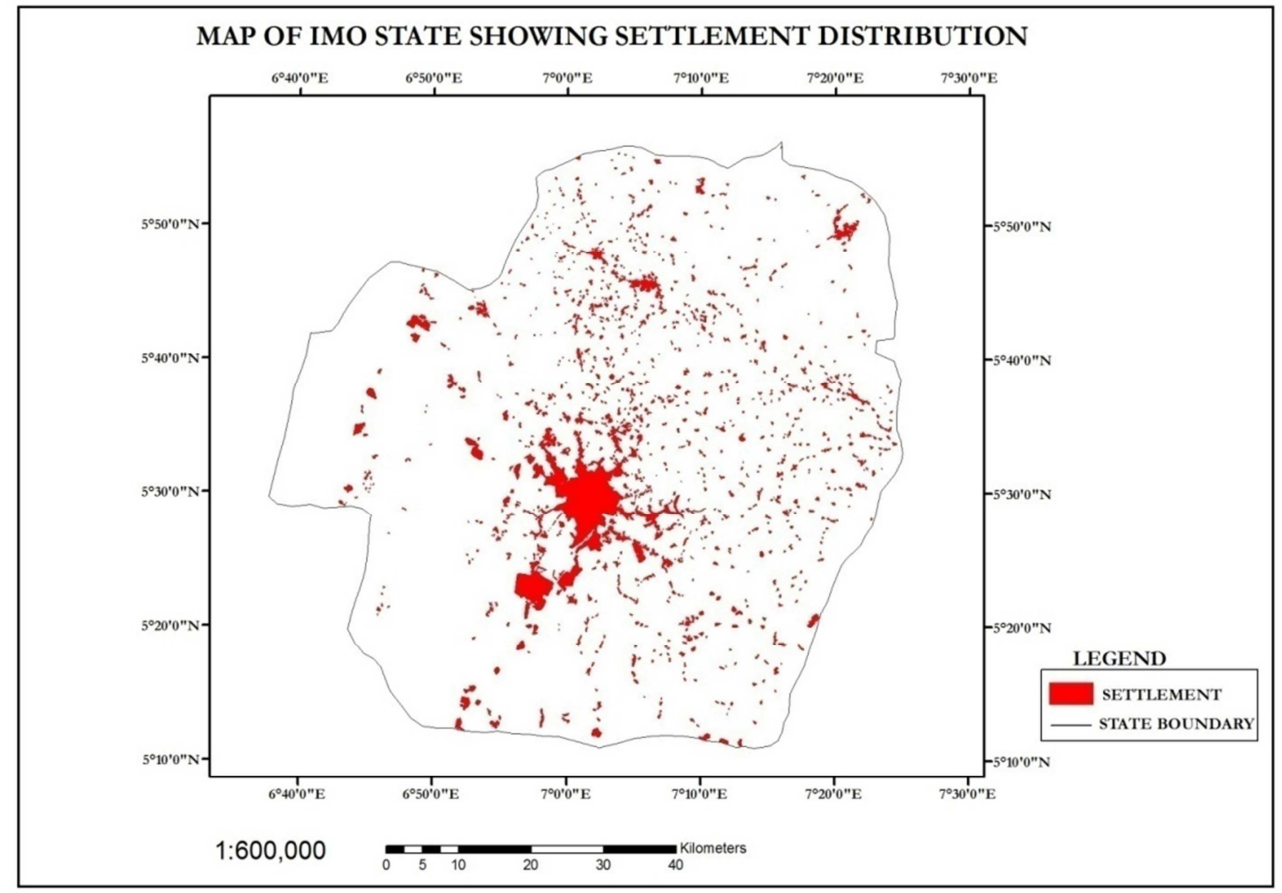

Fig. 4. Settlement map of Imo State from NigSat1( Source ASTAL Uyo).

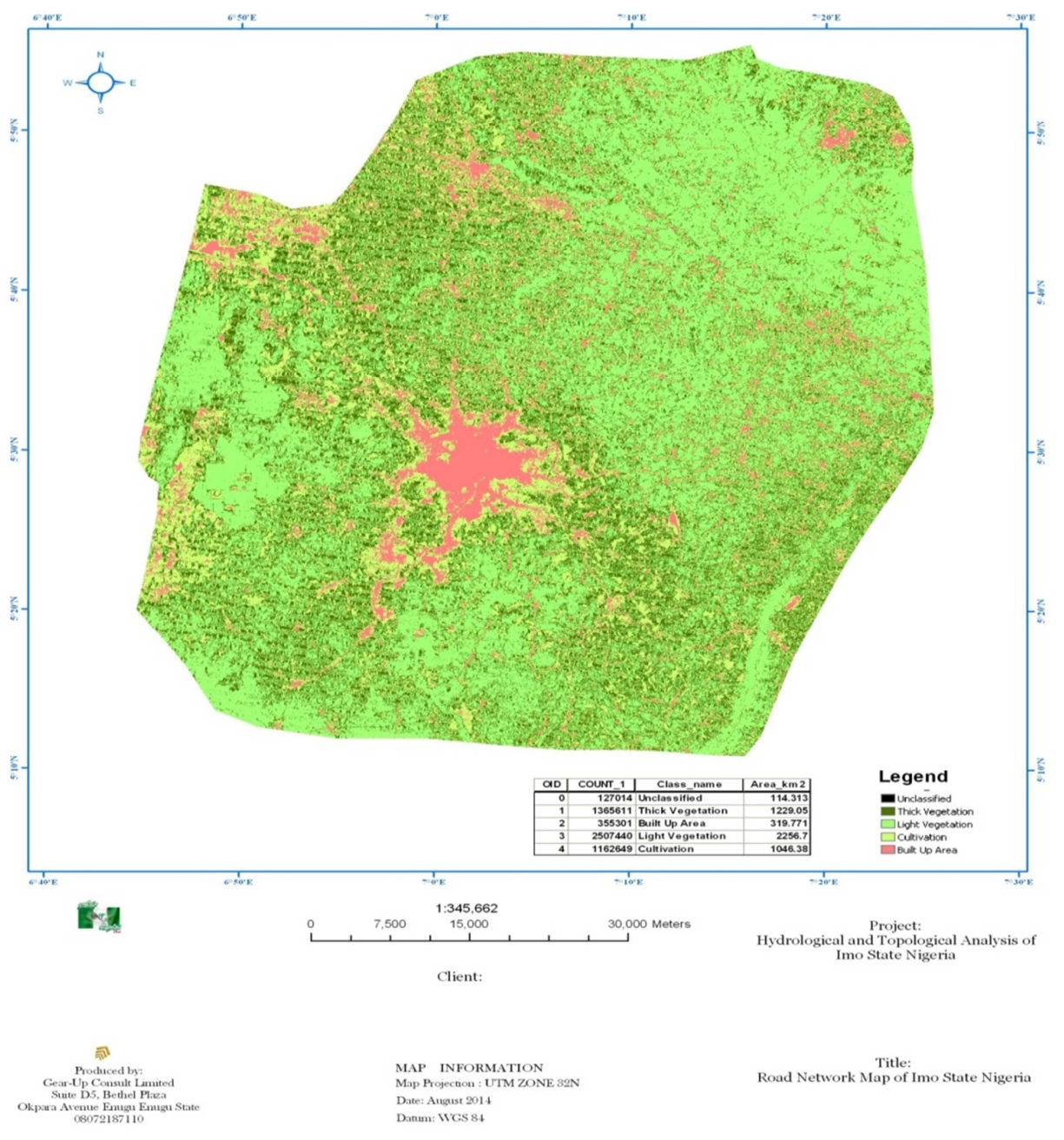

Fig. 5. Land use map of Imo State. 
Fallowing has been traditionally used as a soil management and fertility restoration strategy as vegetative regrowth during fallowing helps these processes. Where there has been persistent population pressure on arable land, the length of the fallowing period has shortened over time leading to continuous cropping.

Tillage operations are sometimes carried out along slopes. Furrows formed along slopes cannot slow down runoff compared to those made along contours. Cultivation into fine soil tilts also makes the soil vulnerable to erosion during the early part of the main rainy season. Management of animals and their feed sources is also a major contributor to soil erosion in parts of the region. Mass movement of soil can be caused by human activity and land use change.

\subsection{Vegetation and Land Cover of Imo State}

Results from the study show that $45.4 \%$ of the land cover of Imo State representing $2256.7 \mathrm{Km}^{2}$ is covered by light vegetation whereas $24.7 \%$ of the land area representing 1229 $\mathrm{Km}^{2}$ is covered by thick vegetation (Fig. 5). The result also showed that a large percentage of the entire land area $(21 \%)$ representing $1046.3 \mathrm{Km}^{2}$ is cultivated whereas $6.4 \%$ representing $319 \mathrm{Km}^{2}$ is built up with houses and infrastructure like roads, bridges etc.

The area covered by thick vegetation $(24.7 \%)$ is categorized under slightly vulnerable to stable. A larger percentage (45.4\%) is covered by light vegetation, and therefore, classified as moderately vulnerable to erosion whereas $27.4 \%$ comprising cultivated and built up areas are classified as highly to extremely vulnerable to erosion.

Throughout the world, the lowest erosion rates, ranging from 0.004 to $0.5 \mathrm{t} / \mathrm{ha}$ per year, are found in undisturbed forests (Pimentel et al. 1998). However, once forest land is converted to agriculture, erosion rates increase because of vegetation removal, over-grazing and tilling. Vegetation cover reduces erosion. Living and dead plant biomass reduces soil erosion by intercepting and dissipating raindrops and wind energy. Above-ground foliage slows the velocity of water running over the soil decreasing the volume of water and soil lost in surface runoff. Plant roots physically bind particles, thus stabilising the soil and increasing its resistance to erosion. Plant roots also enhance water conservation by creating pores in the soil surface that enable water to enter easily into the soil matrix. The uptake of water by plant roots also depletes the soil water content and thereby further increases infiltration rates.

In recent times, felling of trees for fuel, wood and charcoal without replacement has become a serious problem contributing to the loss of vegetation and hence to increased soil erosion. The increase in the human population has reduced land holding per capita and created pressure on limited land for agricultural production. Also, the removal or destruction of vegetation cover through overgrazing and bush burning etc. leads to land degradation as such practices leave soils bare and exposed to erosion and other degradation processes.

\subsection{Soil Properties}

The major soil class found in Imo State is Ultisols. However, several different types of Ultisols are found in different places at lower classification levels and that infers that each of these has properties that affect soil degradation differently. Soils vary in their resistance to erosion partly based on texture and amount of organic matter. The resistance also depends on soil condition and depth. Soils high in silt and low in clay and sand are highly erodible (Nill et al. 1996). The high erodibility of silty soils is explained by their weak structural stability. They rapidly form surface seals upon the impact of rain drops. Erosion is less on clayey soils due to better aggregation and on sandy soils due to the non-sealing surface. Most of the differences in soil characteristics highly depend on the type of parent material found in the study area.

A total of seven (7) different parent materials were found in the study area. As earlier mentioned, five sites representing four of the seven parent materials were identified in the study area and soil samples and field measurements taken from the sites to complement GIS studies. The results (Table 2) showed that all the soils exhibited very high dispersion ratios ranging from $58-82 \%$. As expected, the dispersion ratios were affected by the type of underlying parent material. The highest dispersion ratios were found in Nneato (82\%) and Ihube (78\%) representing sites in Upper Coal measures. Oguta site representing Alluvium (Lacustrine Deposit) had a dispersion ratio of $71 \%$ whereas Oforola Owerri site representing Coastal Plain Sandsand Aronizogu representing Clay Shale had dispersion ratios of 63 and $58 \%$ respectively. According to Middleton (1930) soils having dispersion ratio greater than $15 \%$ are erodible in nature. Dispersive soils are structurally unstable and therefore highly susceptibility to erosion mainly due to the high sodium content. A dispersive soil can become rapidly deflocculated even in still water with low dissolved salt concentration (Shoghi et al., 2013).

\subsection{Topography and Hydrology of Imo State}

Imo State's topography consists of high altitudes and rugged landscapes, as described earlier. The rugged topography and steep slopes affect soil erosion rate through its morphological characteristics. Two of these, namely gradient and slope length, are essential components in quantitative relationships for estimating soil loss (Wischmeier and Smith 1978).

Results of the study show that most parts of the state $\left(4133 \mathrm{Km}^{2}\right)$ representing $84 \%$ of the entire landscape fall into slightly to less vulnerable to erosion with a slope class between $1-4 \%$ slope. However, $569.3 \mathrm{Km}^{2}$ of land representing $12 \%$ of the land area are moderately vulnerable to erosion whereas $4.5 \%$ of the entire land area is highly to extremely vulnerable to erosion with slope class of between 7- $>12 \%$ (Fig. 6). These results concur with that on Fig. 7 showing analysis of hill shading for Imo state which showed that $87 \%$ of the area shaded fall within the highest heights of 
$176-187 \mathrm{~m}$ and above whereas the remaining part (13\%) fall within heights lower than $176 \mathrm{~m}$. Hill shading is the shadows drawn on a map to simulate the effect of the sun's rays over the varied terrain of the land.It is a hypothetical illumination of a surface according to a specified azimuth and altitude for the sun. Hill shading creates a three-dimensional effect that provides a sense of visual relief for cartography, and a relative measure of incident light for analysis.
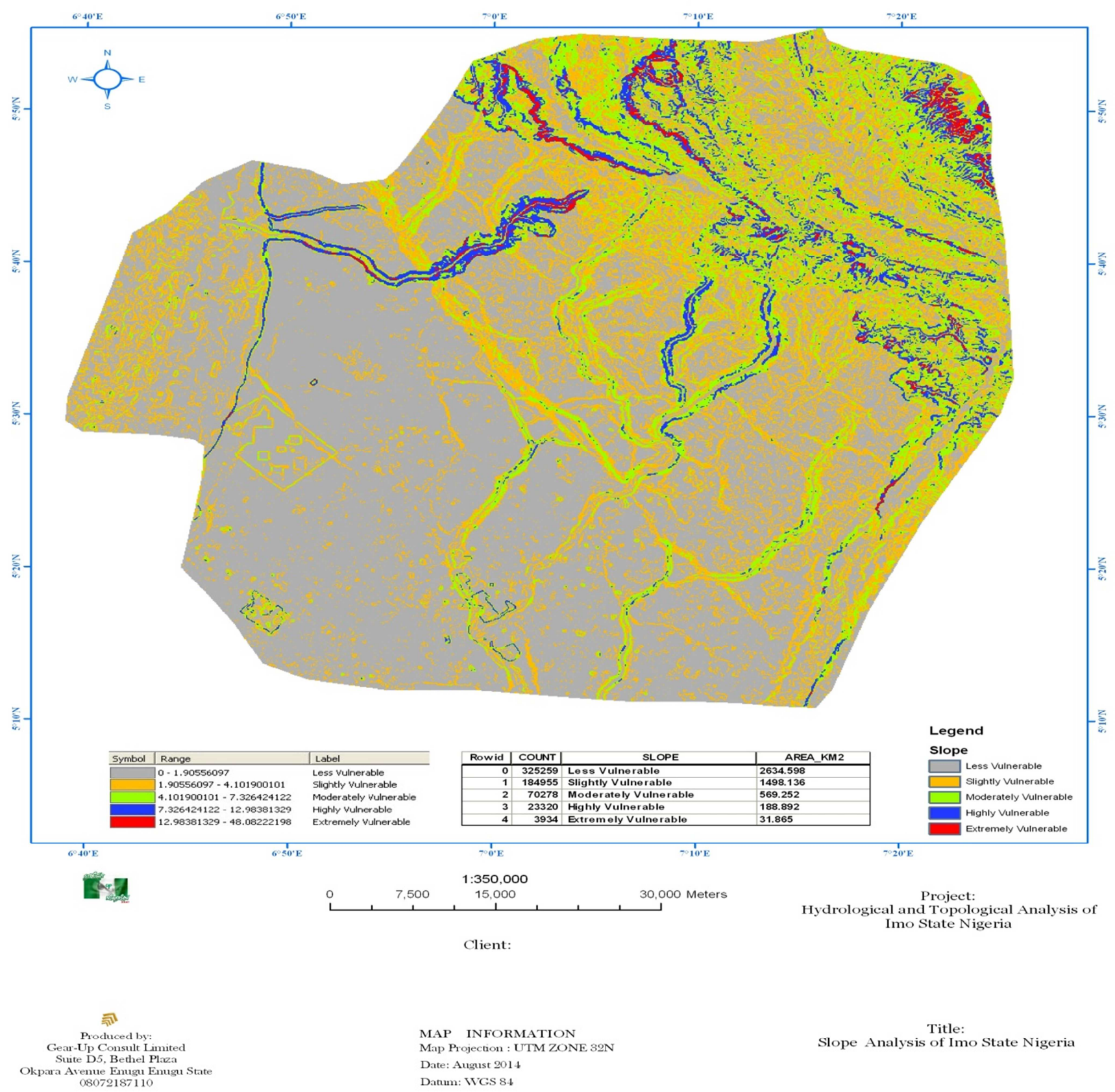

MAP INFORMATION
Map Projection : UTM ZONE 32N

Date: August 2014

Datum: WGS 84
Title:

Slope Analysis of Imo State Nigeria

Fig. 6. Slope Model of Imo State, Nigeria. 


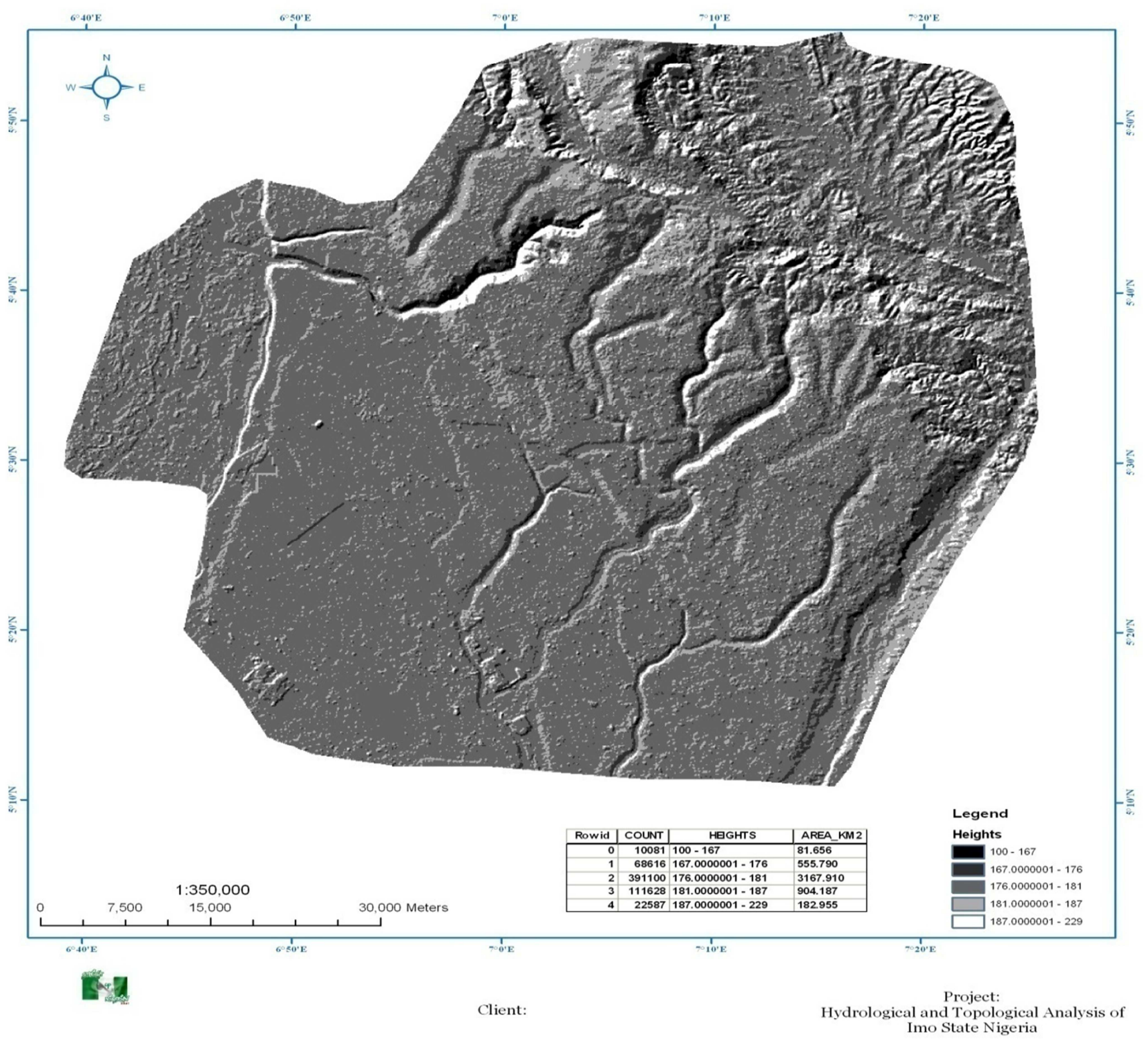

ज亦 Produced by:
Gear-Up Consult Limited Suite D5, Bethel Pliza Okpara Avenue Enugu Enugu State 08072187110
MAP INFORMATION

Map Projection : UTM ZONE 32N Date: August 2014 Danu. WCS 8
Title:

Hillshade Analysis of Imo State Nigeria

Fig. 7. Hill Shade Model of Imo State, Nigeria. 


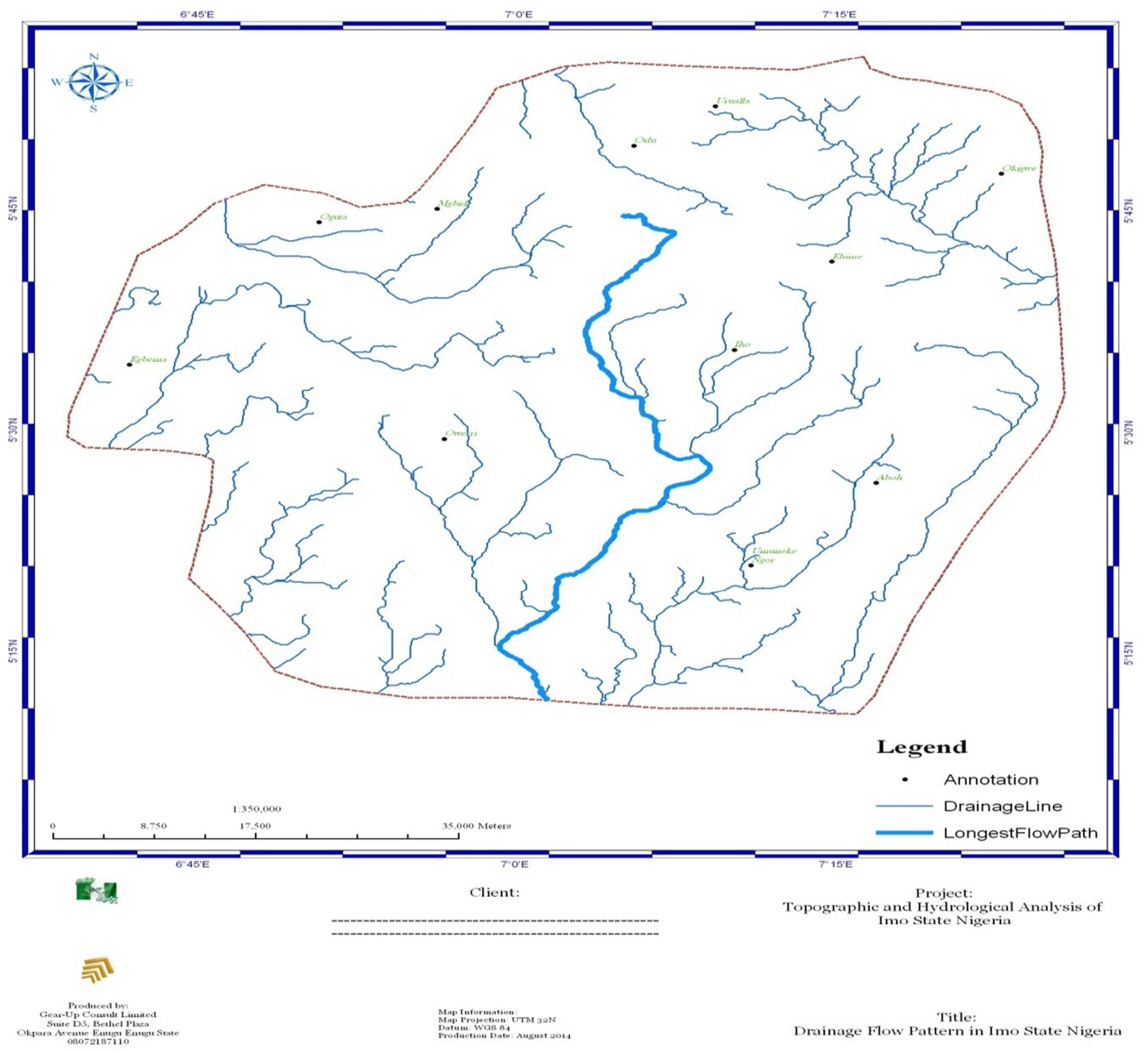

Fig. 8. Drainage Model of Imo State, Nigeria. 


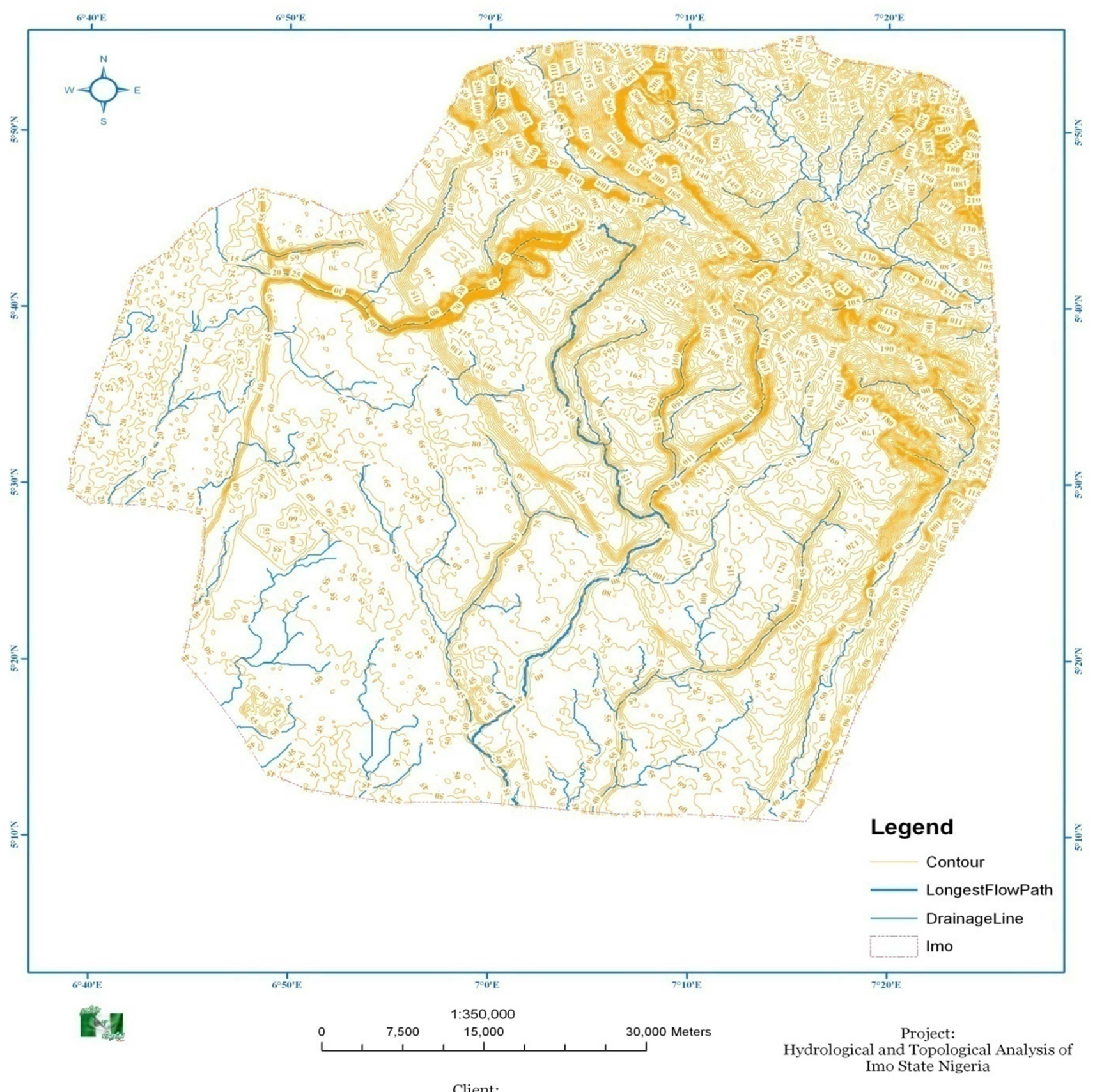

司

Produced by:

Gear-Up Consult Limited

Okpara Avenue Enugu Enugu State
MAP INFORMATION

Map Projection : UTM ZONE 32N

Date: August 2014

Datum: WGS 81
Title:

Elevation and Drainage Analysis of Imo State Nigeria

Fig. 9. Elevation and Drainage overlay model ofImo State. 

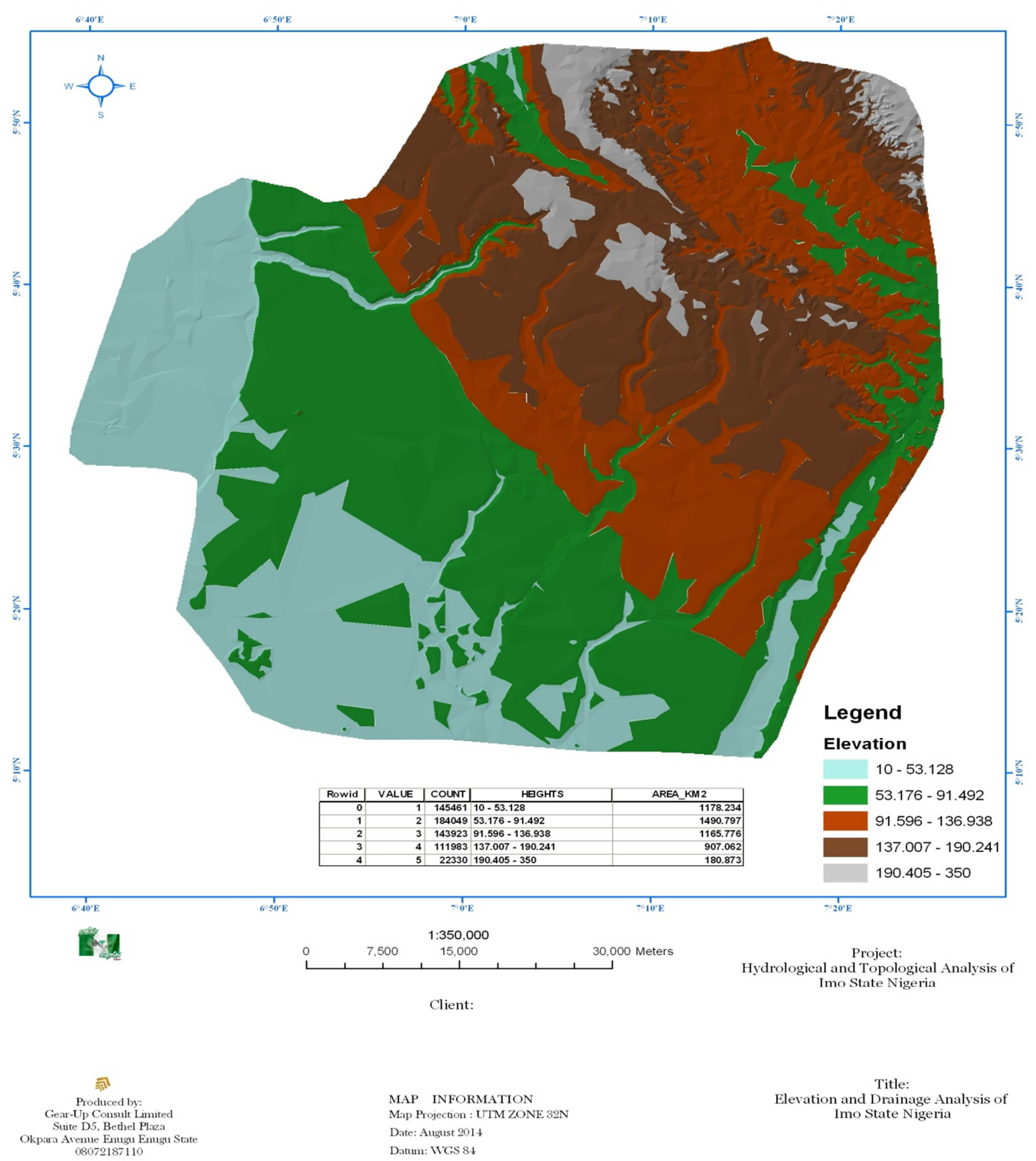

MAP INFORMATION

Map Projection : UTM ZONE 32N

Title:

Date: August 2014

Elevation and Drainage Analysis of Datum: WGS 84

Fig. 10. Elevation Model/Drainage Overlay analysis of Imo State, Nigeria.

Results of the elevation and drainage analysis (Fig. 8, 9 and 10 ) follow the previous trend depicting that $78 \%$ of the entire land area representing $3833 \mathrm{Km}^{2}$ fall within less to moderately vulnerable erodibility class.

On sloping lands, more than one-half of the soil particles that are dislodged by raindrops during rainfall are carried downhill. Erosion increases dramatically because the increased angle facilitates water flow and soil movement. It is not surprising, therefore, that areas on the highest elevations suffer some of the state's highest erosion rates.

Data for assessment of the effect of slope gradient and length on soil erosion is limited. However, it is generally accepted that an increase in slope and slope length will increase erosion because they lead to an increase in overland flow volume and velocity. Runoff on low slopes flows slowly and quickly forms a water layer deep enough to act as surface 
mulch. Increasing slope length enhances soil loss as more runoff can accumulate on long slopes. Thomas (1991) identified that slope shape together with ground/field attributes exercise a strong influence on the nature and extent of visible erosion damage.

On steep slopes, soils are generally shallower and their nutrient and water storage capacities are limited. Thus, soils in these areas, when exposed to soil eroding agents, face greater degradation consequences compared to soils in flat areas. Since most of the terrain of the highlands of the region is undulating and hilly, most agricultural land is situated on sloping ground. Increasing population has resulted in an increasing demand for cultivable land which has increasingly moved on to steeper slopes previously covered (through cutting and burning) by forests.

\section{Conclusions}

Results show that most of the soils in the study (79.9\%) are classified as highly to moderately vulnerable to erosion based on the RUSLE soil erodibility classification. This means that the combined effect of cultivation (33\%), light vegetation $(37.2 \%)$ and human settlements $(9.1 \%)$ combine to expose the soils to greater risk of gully erosion. Thus $80 \%$ of the soil of Imo State will be classified as highly vulnerable to erosion. However, the total percentage area under thick vegetation is $18.3 \%$ and this area fall under slightly vulnerable classification. The natural vegetation protects the soil against the impacts of rainfall and it is a source of organic matter to the soil. These factors improve infiltration and enhance the recharging of groundwater reservoirs. When vegetation cover is displaced, infiltration capacity is decreased, resulting in surface runoff, which will carry sediments and nutrients into rivers (Van Oost et al., 2000; Zuazo and Pleguezuelo, 2008). Moreover, changes in precipitation volume and intensity caused by climate changes may increase the energy available in rainfall for detaching and carrying sediments. According to Yang et al. (2003), the global average soil erosion is projected to increase approximately $9 \%$ by 2090 due to climate changes.

Although soil erosion is a natural and inevitable process, the accelerated rates of soil loss, caused by the factors mentioned above, represent a serious environmental problem. For instance, increased rates of soil erosion are directly associated with nutrient loss, which may reduce agricultural productivity (Bakker et al., 2007) and cause water bodies' eutrophication (Istvánovics, 2009). In some cases, advanced stages of soil erosion, such as rill and gully erosions, can devastate entire areas, turning them unusable for agricultural purposes (Valentin et al., 2005; Kirkby and Bracken, 2009).

\section{References}

[1] Asiabaka, C. C., \& Boers, T. M. (1988). An Analysis of existing traditional methods of Farming and Erosion Control among Farmers in South Eastern Nigeria. In Proceeding of First International Symposium on Erosion in South Eastern Nigeria (Vol. 1, No. 1, pp. 109-114).
[2] Bakker, M. M., Govers, G., Jones, R. A., Rounsevell, M. D. A., 2007. The effect of soilErosion on Europe's crop yields. Ecosystems 10, 1209-1219.

[3] Dane, J. H., \& Hopmans, J. W. (2002). Water retention and storage. Methods of soil analysis. Part, 4, 671-717.

[4] Egboka, B. C. E. (2004). Distress Call and Plea to the Senate Committee for Urgent Actions Against Floods, Soil/Gully Erosion/ Landslides Disasters in the Southeast. Paper Presented to Senate Committee on Environment: Roads/Erosion Senate Delegation to the Southeast. 30p.

[5] Gee GW and Bauder JW1986 Particle size analysis. In Methods of Soil Analysis. Part I. Agronomy 9. Ed. A. Klute. pp. 383-411.Am. Soc. Agron., Madison, WI. USA.

[6] Igbokwe, J. I., Akinyede, J. O., Dang, B., Alaga, T., Ono, M. N., Nnodu, V. C., \& Anike, L. O. (2008). Mapping and monitoring of the impact of gully erosion in Southeastern Nigeria with satellite remote sensing and Geographic Information System. The International Archives of the Photogrammetry, Remote Sensing and Spatial Information Sciences, 37, B8.

[7] Istvánovics, V. 2009. Eutrophication of lakes and reservoirs, p. 157-165. In: G.E. Likens [ed.], Encyclopedia of Inland Waters, vol. 1. Elsevier, Oxford.

[8] Kirkby, M. J., \& Bracken, L. J. (2009). Gully processes and gully dynamics. Earth Surface Processes and Landforms, 34(14), 1841-1851.

[9] Middleton, H. E. 1930. Properties of soil which influence soil erosion. U. S. Dept Agronomy Tech. Bull. 178pp.

[10] Mulla, D. J., \& McBratney, A. B. (2010). 9 Soil Spatial Variability. Soil physics companion, 343.

[11] Nill D., Schwertmann U., Sabel-Koschella U., Berhard M. and Breuer J. 1996. Soil erosion by water in Africa. Principles, prediction \& protection. GTZ, Germany. $292 \mathrm{pp}$.

[12] Ofomata, G. E. K. (1985). Soil Erosion in Nigeria: The Views of a Geomorphologist. 7th Inaugural Lecture. University of Nigeria, Nsukka, Nigeria. pp.

[13] Ogbonna, J. U. (2012). Understanding Gully Erosion Vulnerability in Old Imo State Using Geographic Information System and Geostatistics. American Journal of Geographic Information System, 1(3), 66-71.

[14] Okoro, B. C., Uzoukwu, R. A., \& Chimezie, N. M. (2014). River Basins of Imo State for Sustainable Water Resources Management. Journal of Civil \& Environmental Engineering 4,130-138.Pimentel, D., Harvey, C., Resosudarmo, P., Sinclair, K., Kurz, D., McNair, M \& Blair, R. (1998). Land use, erosion and water resources. Water resources, environmental planning, management, and development. Tata McGraw-Hill Publishing Limited, New Delhi, India, 37-71.

[15] Shoghi, H, Ghazavi M, Kazemain, S, Moayedi H (2013) A state of the art review of dispersive soils. Identification methods perspectives. European Journal of Scientific Research107: 322-328.

[16] Thomas, T. 1991. Aspects of soil degradation and conservation measures in Agucho catchment, West Hararghe. Soil Conservation Research Project Report 19. University of Bern, Switzerland. $125 \mathrm{pp}$.

[17] Udo, R. K. (1970). Geographical regions of Nigeria. Univ of California Press. 
[18] Valentin, C., Poesen, J., \& Li, Y. (2005). Gully erosion: impacts, factors and control. Catena, 63(2), 132-153.

[19] Van Oost, K., Govers, G., \& Desmet, P. (2000). Evaluating the effects of changes in landscape structure on soil erosion by water and tillage. Landscape ecology, 15(6), 577-589.

[20] Wischmeier, W. H., \& Smith, D. D. (1978). Predicting rainfall erosion losses-A guide to conservation planning. Predicting rainfall erosion losses-A guide to conservation planning.
[21] Yang, D., Kanae, S., Oki, T., Koike, T., Musiake, K., 2003. Global potential soil erosion with reference to land use and climate changes. Hydrological Processes 17, 2913-2928.

[22] Zuazo, V. H. D., \& Pleguezuelo, C. R. R. (2009). Soil-erosion and runoff prevention by plant covers: a review. In Sustainable Agriculture (pp. 785-811). Springer Netherlands. 